\title{
Antibacterial Activity of Bougainvillea glabra, Eucalyptus globulus, Gnaphalium attenuatum, and Propolis Collected in Mexico
}

\author{
Oswaldo Javier Enciso-Díaz ${ }^{1}$, Alfonso Méndez-Gutiérrez², Lourdes Hernández De Jesús ${ }^{3}$, \\ Ashutosh Sharma ${ }^{1}$, María Luisa Villarreal ${ }^{1}$, Alexandre Cardoso Taketa ${ }^{{ }^{*}}$ \\ ${ }^{1}$ Biotechnology Research Center (CEIB), Autonomous University of Morelos State (UAEM), Morelos, Mexico; ${ }^{2}$ Center for Research \\ and Teaching in Humanities of the State of Morelos (CIDHEM), Morelos, Mexico; ${ }^{3}$ Department of Pharmacy, National School of \\ Biological Sciences, National Polytechnic Institute (IPN), Mexico City, Mexico. \\ Email: *ataketa@uaem.mx
}

Received July $4^{\text {th }}$, 2012; revised August $12^{\text {th }}, 2012$; accepted September $14^{\text {th }}, 2012$

\begin{abstract}
Bougainvillea glabra C., Eucalyptus globulus Labill., and Gnaphalium attenuatum DC., as well as propolis, have been used in Mexican traditional medicine as a remedy to treat respiratory illnesses. There are few biological reports of such material collected in Mexico, despite the high demand for them as raw material for popular and industrial uses. The antibacterial activity of the plants and propolis studied here were evaluated against a panel of bacteria using three different methodologies: agar disc diffusion, macro and micro dilution methods. E. globulus and G. attenuatum extracts showed the strongest active values $(\mathrm{P}>0.05)$ in the agar disc diffusion method with a range of $8-22 \mathrm{~mm}$ inhibition zone, MIC values ranging from $25-250 \mu \mathrm{g} / \mathrm{mL}$, and MBC values of $25-500 \mu \mathrm{g} / \mathrm{mL}$ obtained by macro and micro dilution methods. B. glabra extracts were active against E. coli, S. typhi, K. pneumoniae, S. aureus and S. agalactiae, with 8 - $13 \mathrm{~mm}$ inhibition zone, MICs ranging from $500-3000 \mu \mathrm{g} / \mathrm{mL}$, and MBCs of 1000 - $3000 \mu \mathrm{g} / \mathrm{mL}$. The propolis extract turned out to be active against E. coli, K. pneumoniae, S. aureus and S. agalactiae, with values of $7-12 \mathrm{~mm}$, MICs of $1000-2000 \mu \mathrm{g} / \mathrm{mL}$, and MBCs of $2000-2500 \mu \mathrm{g} / \mathrm{mL}$. E. globulus and G. attenuatum extracts were the most active in the three methodologies assayed. This is also the first time that the antibacterial activity of G. attenuatum has been experimentally demonstrated. The microdilution method showed to be more sensitive, less expensive and minor time-consuming technique compared with the other two.
\end{abstract}

Keywords: Antibacterial Activity; Bougainvillea glabra; Eucalyptus globulus; Gnaphalium attenuatum; Mexican Ethnomedicine; Propolis

\section{Introduction}

Acute respiratory infections represent a serious health problem worldwide, and in Mexico, in the 2008 national statistics list, these infections occupied the first position in the top 20 illness affecting more than 24 million people, especially young children between 1 and 4 years [1]. Mexico has an ancient tradition in the use of medicinal plants as first aid remedies, which actually remains in use now. An important number of products derived from plants are used to manufacture a broad range of herbal formulas for the treatment of respiratory diseases, which are commercialized in such different forms, as infusions, plasters, syrups, pills, and candies. These products are usually registered as supplements or dietary aids in order to avoid the more strict governmental

${ }^{*}$ Corresponding author. health policies [2]. The local market is flooded with a variety of herbal products lacking any kind of quality control guarantying efficacy and safety. The most important missing issue is a scientific approach to the specification of the concentration levels of the crude extracts, as well as the pharmacological activity and safety. Some medicinal plants such as Bougainvillea glabra C. (Nyctaginaceae), Eucalyptus globulus Labill. (Myrtaceae) and Gnaphalium attenuatum DC. (Compositae), as well as extracts from propolis, are popularly employed alone or in combination. Neglected is the importance of characterizing a plant extract in terms of the origin of the raw material: local, seasonality and ontogenetic variations depending on its site of collection for. It has been demonstrated that the metabolic profiling of a plant species can change dramatically affecting the pharmacological response in relation to different environments $[3,4]$. In the same way, 
propolis, a resin with a highly complex composition, can present different antimicrobial effectiveness depending on the solvent used in the extraction process, as well as the origin of the resin [5].

Although there are guidelines, the reality is that researchers adopt a wide range of criteria which depends on individual situations and conditions to define such parameters as plant material, techniques employed, growth medium and tested microorganisms in the antibacterial studies of medicinal plants [6]. This complex issue alerts us to the need to define the pharmacological properties of a plant material in time and space. Even though there are a number of antibacterial studies of Bougainvillea glabra [7,8], Eucalyptus globulus [9-11], Gnaphalium sp. [12, $13]$, and propolis [5,14], each one was based on only one methodology. On the contrary, we are reporting the activity of these same plants, collected in the state of Morelos, as well as propolis from Oaxaca State, Mexico, which we subjected to three different methodologies: agar disc diffusion, macro and micro dilution methods. The panel of Gram positive bacteria included Staphylococcus aureus, Streptococcus agalactiae, Listeria monocytogenes and Bacillus subtilis; and the Gram negative bacteria were Escherichia coli, Klebisiella pneumoniae and Salmonella typhi.

\section{Materials and Methods}

\subsection{Plant Material}

Plants were collected in Morelos State, Mexico, in the year 2007, and propolis samples were collected from beehives in March, 2007, in Oaxaca State, Mexico. Voucher specimens were authenticated by Juan Carlos Juárez and then deposited at the HUMO Herbarium, CEAMISH (Centro de Educación Ambiental e Investigación Sierra de Huautla) UAEM, under the numbers 26348 (B. glabra), 26347 (E. globulus), and 26346 (G. attenuatum).

\subsection{Preparation of Plant Extracts}

Dried aerial part of the plants (200 g) were powdered and put into a container with $300 \mathrm{~mL}$ of cold water, and then heated to boiling. After cooling down the mixture decoction to room temperature, $700 \mathrm{~mL}$ of $\mathrm{EtOH}$ was added, and then macerated for 2 weeks in a dark and cool place. This procedure has been used by some industries to prepare a mother tincture. In this study, these macerates were filtered and the solvent was evaporated under reduced pressure to obtain an extract that was used to prepare the dilutions employed for the biological testing. Plant crude extracts and propolis resin were dissolved in ethanol or DMSO prior to use in the antibacterial assay.

\subsection{Test for Antibacterial Activity}

The minimal inhibitory concentration (MIC) and the minimal bactericidal concentration (MBC) were established for the hydroalcoholic extracts for each species, and for the propolis extract, using both macro and micro dilution methods with tetrazolium chloride dyeing agent. Additionally, a disc diffusion method was applied to record the diameter of inhibitory zone promoted by the extracts. The antibacterial tests were adapted from the National Committee for Clinical Laboratory Standards (CLSI), formerly NCCLS, guidelines for document M26-A (1999) [15] and M38-A (2002) [16].

\subsection{Microorganisms}

The bacteria used in the present study were Gram positive: Staphylococcus aureus (ATCC 25923), Streptococcus agalactiae (ATCC 25924), Listeria monocytogenes

(ATCC 244), and Bacillus subtilis (ATCC 6633); and Gram negative: Escherichia coli (ATCC 25922), Klebisiella pneumoniae (ATCC 10031) and Salmonella typhi (ATCC 6539). The bacteria were provided from the Microbiology Laboratory Culture Collection, National School of Biological Sciences, National Polytechnic Institute, Mexico. The microorganisms were first incubated at $37^{\circ} \mathrm{C}$ $\pm 0.1^{\circ} \mathrm{C}$ for $24 \mathrm{~h}$ in the nutrient broth (Mueller-Hinton). The bacterial suspensions were prepared and adjusted by comparison against 0.5 of the MacFarland turbidity standard $\left(5 \times 10^{7}\right.$ cells $\left./ \mathrm{mL}\right)$ tubes, and further diluted to obtain a final concentration of $5 \times 10^{6}$ cells $/ \mathrm{mL}$ that was standardized in our laboratory by a turbidity measure at $420 \mathrm{~nm}$ wavelength prior to use.

\subsection{Agar-Disc Diffusion Method}

Sterilized filter papers discs with $6 \mathrm{~mm}$ diameter were impregnated with $2 \mathrm{mg}$ extracts, and then placed into Petri dishes $(9 \mathrm{~cm})$ with Mueller-Hinton agar (Oxoid), which were previously streaked with a swab containing the bacteria. The plates were incubated at $37^{\circ} \mathrm{C} \pm 0.1^{\circ} \mathrm{C}$ for $24 \mathrm{~h}$. Diameter of inhibition zones appearing around the discs were measured and recorded in mm. Chloramphenicol ( $2 \mu \mathrm{g} / \mathrm{disc})$ was used as a positive control, and negative control discs were prepared with ethanol only.

\subsection{Microdilution Method (MiD)}

Dilutions of the extracts solubilized in DMSO were prepared and dispensed into 96 microdilution wells to obtain a final volume of $200 \mu \mathrm{L}$ at a concentration range of $25-3000 \mu \mathrm{g} / \mathrm{mL}$ of inoculum suspension. Microdilution trays were incubated at $37^{\circ} \mathrm{C} \pm 0.1^{\circ} \mathrm{C}$ for $24 \mathrm{~h}$ to determine the MIC and the MBC. To establish the MIC values, $20 \mu \mathrm{l}$ of tetrazolium chloride at $20 \mathrm{mg} / \mathrm{mL}$ in 
water was added to each well. After incubation at $37^{\circ} \mathrm{C} \pm$ $0.1^{\circ} \mathrm{C}$ for $30 \mathrm{~min}$, the presence of live bacteria was recorded by visual inspection using the red formazan derivative. Before the addition of tetrazolium chloride, an aliquot was taken from the wells, where the turbidity was absent, and then inoculated in a tube with broth medium. The concentration point in which the bacterial growth was not observed was defined as the MBC value.

\subsection{Macrodilution Method (MaD)}

Extracts were assayed at the same concentration and inoculation conditions as those used in the MiD method; however, a volume of $2 \mathrm{~mL}$ inoculums per tube was employed. The determination of MIC and MBC were carried out in the same way explained above for the MiD method.

\section{Results}

Extraction procedures yielded $2.89 \%, 6.11 \%$, and $2.60 \%$ w/w of the hydroalcoholic extracts of B. glabra, E. globulus and G. attenuatum, respectively. The results of bacterial susceptibility testing for these extracts, as well as for propolis, are reported in Table 1. The crude extracts of $E$. globulus showed to be the most active one, with MIC values lower than $25 \mu \mathrm{g} / \mathrm{mL}$ and up to $50 \mu \mathrm{g} / \mathrm{mL}$ (MiD), $50-100 \mu \mathrm{g} / \mathrm{mL}(\mathrm{MaD})$, and MBC values of $<25-100$ $\mu \mathrm{g} / \mathrm{mL}$ (MiD), $<25-250 \mu \mathrm{g} / \mathrm{mL}(\mathrm{MaD})$, and diameter of inhibitory zone at $8-22.5 \mathrm{~mm}$, against all bacteria assayed ( $\mathrm{P}>0.05)$. G. attenuatum turned out to be the second most active extract, with a broad spectral action against all tested strains, and with MIC values of 50 $200 \mu \mathrm{g} / \mathrm{mL}$, MBC of $100-250 \mu \mathrm{g} / \mathrm{mL}$, and diameter of inhibitory zone of 8 - $21.5 \mathrm{~mm}$.

Table 1. Antibacterial activity of crude extracts of B. glabra, E. globulus, G. attenuatum, and propolis using different methodologies.

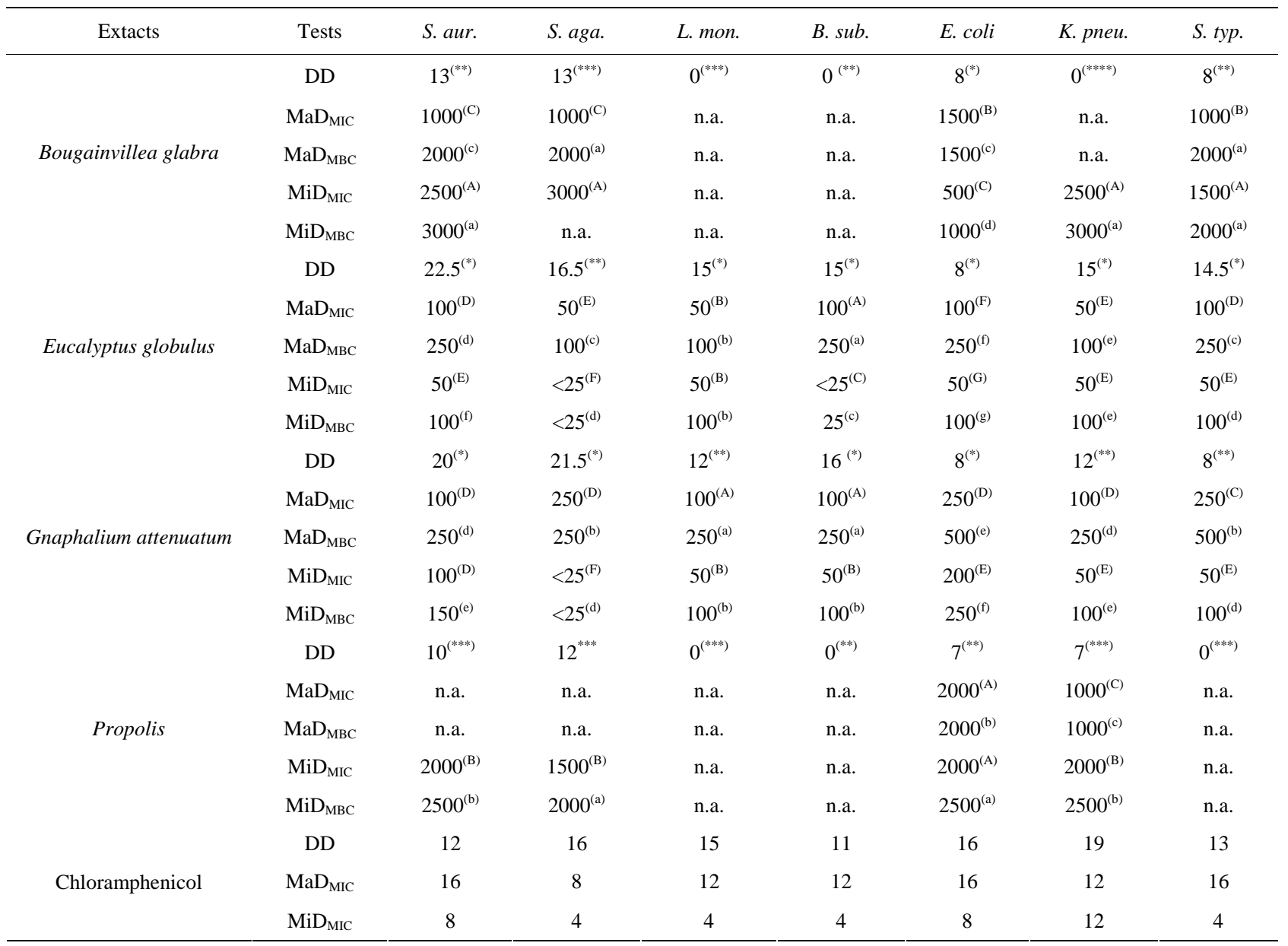

DD: disc diffusion method (mm); MaD: macrodilution method ( $\mu \mathrm{g} / \mathrm{mL})$; MiD: microdilution method with a 96-well microtiter plate ( $\mu$ g/mL); S. aur. (Staphylococcus aureus), S. aga. (Streptococcus agalactiae), L. mon. (Listeria monocytogenes), B. sub. (Bacillus subtilis), E. coli (Escherichia coli), K. pneu. (Klebsiella pneumonia), and S. typ. (Salmonella typhi); n.a.: no active at a concentration of $3000 \mu \mathrm{g} / \mathrm{mL}$. Values presented are averages of three replicates. Values in parentheses in the same column following different asterisk, capital, and lower case letters designate a significant difference, in the DD, MICs, and MBCs values, respectively, by Duncan's multiple range test, $\mathrm{P}<0.05$. 
B. glabra crude extract was mildly active against $S$. aureus, S. agalactiae, E. coli, and S. typhi, with MIC values of $500-3000 \mu \mathrm{g} / \mathrm{mL}$ (MiD), $1000-1500 \mu \mathrm{g} / \mathrm{mL}$ $(\mathrm{MaD})$, and MBC of $1000-1500 \mu \mathrm{g} / \mathrm{mL}(\mathrm{MiD})$ and 1500 $2000 \mu \mathrm{g} / \mathrm{mL}$ (MiD), and diameter of inhibitory zone at 8 $13 \mathrm{~mm}(\mathrm{P}>0.05)$. This extract was not active against $L$. monocytogenes and $B$. subtilis at the maximal dosis assessed of $3000 \mu \mathrm{g} / \mathrm{mL}$. Propolis extract resulted to posses a weak activity against $S$. aureus, S. agalactiae, $E$. coli, and K. pneumoniae, with MIC values of 1500 $2000 \mu \mathrm{g} / \mathrm{mL}$, MBC of $2000-2500 \mu \mathrm{g} / \mathrm{mL}$, and diameter of inhibitory zone of $7-12 \mathrm{~mm}$.

\section{Discussion}

The microplate and tube macro dilution methods employing tetrazolium chloride dyeing agent, as well as the disc diffusion assay, are currently used methods applied to determine the antibacterial potency of crude extracts derived from natural products $[17,18]$. In the present work, the three methods were used to compare the activity of some important plants employed in Mexican folk medicine to treat respiratory diseases. These three methods covered a broad intrinsic variability of each technique, and extract complexity, and also permitted the comparison of the data obtained in this study with previously reported literature. In general, the MiD method was more sensitive and quick than the $\mathrm{MaD}$ assay, requiring a smaller sample amount. Additionally, we performed the disc diffusion method to compare our results with data from literature. This method is largely used due to it is a reliable, easy and inexpensive susceptibility test. In some occasions, the most active extract employing the disc diffusion assay did not agree with that determined by MiD test.

The genus Bougainvillae comprises 18 species, and some of them have been used in traditional medicine to treat such disorders as diarrhea, stomach acidity, cough, sore throat, leucorrohea, hepatitis, and as an anti-inflammatory, antiviral and antibacterial agent [7,8]. Leaves and inflorescence of Bougainvillaea glabra C. have been used in Mexican traditional medicine as a remedy for such respiratory illnesses as cough, cold, bronchitis and asthma $[18,19]$. Its antimicrobial effect can be associated with the presence of betalains pigments [20], as well as steroidal compounds with anti-inflammatory activity [21]. Gupta et al. (2009) found that a $500 \mu \mathrm{g} /$ disc hydroalcoholic extract from leaves of $B$. glabra was active against S. aureus $(10 \mathrm{~mm})$, B. subtilis $(15 \mathrm{~mm})$, E. coli $(12 \mathrm{~mm})$, $S$. typhi $(14 \mathrm{~mm})$, and $K$. pneumoniae $(16 \mathrm{~mm})$. These results confirmed the level of activity reported in the present study against $S$. aureus $(13 \mathrm{~mm})$, E. coli $(8 \mathrm{~mm})$, and $S$. typhi $(8 \mathrm{~mm})$. However, the extracts were not active against $B$. subtilis and $K$. pneumonia, the most susceptible bacteria reported by Gupta when tested by disc diffusion assay. These differences could be attributed to a chemical profiling variation associated with changes in the plant environment.

The leaves extract and essential oil from Eucalyptus sp. have been used in the traditional medicine of different countries to treat patients with respiratory tract infections [10,11]. A study performed with E. globulus collected in Morelos, Mexico, using the methanolic extract from the leaves, reported MIC values of $5000 \mu \mathrm{g} / \mathrm{mL}$ against $S$. aureus and 10,000 $\mu \mathrm{g} / \mathrm{mL}$ against E. coli [9]. These concentrations are far higher than those MIC values we found in this investigation (S. aureus of $100 \mu \mathrm{g} / \mathrm{mL}$ and to $E$. coli of $100 \mu \mathrm{g} / \mathrm{mL}$, both in the MaD method; and $S$. aureus of $50 \mu \mathrm{g} / \mathrm{mL}$ and to E. coli of $50 \mu \mathrm{g} / \mathrm{mL}$, both in the MiD method). These huge differences can be explained due to intrinsic factors associated with the collected plants, as seasonality and particular environments, that cause a change in the metabolic profiling, and consequently, in its activity.

Gnaphalium sp. infusion is the most common herbal remedy used in Mexican ethnomedicine in the treatment of both adult and children's cough and upper respiratory tract infections [12,13]. It has been reported that extracts from aerial parts of $G$. oxyphyllum, G. liebmannii and $G$. viscosum, exhibited a wider spectrum of activity against S. aureous, B. cereus, S. typhimurium, and E. coli. As far as we know, there are no antibacterial activities reported for G. attenuatum, a very important medicinal plant found from Mexico to Panama [22]. In our study, this plant was active against all tested bacteria, showing the wider spectrum of action, with high inhibition zones (8 $21.5 \mathrm{~mm}$ ) and low MICs ranging between <25 - 200 $\mu \mathrm{g} / \mathrm{mL}(\mathrm{MiD})$ and $100-250 \mu \mathrm{g} / \mathrm{mL}(\mathrm{MaD})$; and $\mathrm{MBC}$ values of $<25-250 \mu \mathrm{g} / \mathrm{mL}(\mathrm{MiD})$ and $250-500 \mu \mathrm{g} / \mathrm{Ml}$ (MaD). There are no biological or chemical studies for $G$. attenuatum, however, Fajardo-Ochoa (2004) reported that Gnaphalium sp. may contain saponins with low narcotizing action responsible for lethargy and respiratory failure in newborns [13].

It has been demonstrated that the propolis extract from the state of Campeche, Mexico, was active against $P$. aeruginosa with a MBC of $3.33 \mathrm{mg} / \mathrm{mL}$, followed by $S$. aureus (MBC of $4.82 \mathrm{mg} / \mathrm{mL}$ ) and Streptococcus pyogenes (MBC of $5.38 \mathrm{mg} / \mathrm{mL}$ ). In that work, S. typhi turned out to be the most resistant bacteria (MBC of $9.82 \mathrm{mg} / \mathrm{mL}$ ) [5]. Our study shows that propolis from Oaxaca was not active against $B$. subtilis, L. monocytogenes and S. typhi, with MIC and MBC values investigated at a maximal concentration of $3 \mathrm{mg} / \mathrm{mL}$. However, this propolis extract exhibited MIC values of $1.50-2.00 \mathrm{mg} / \mathrm{mL}$ and MBC of $2.0-2.5 \mathrm{mg} / \mathrm{mL}$ against E. coli, K. pneumoniae, S. aureus and S. agalactiae, when tested by MiD method. 
In the same way that the antibacterial potency of honey varies very markedly, and depends on the flora source of the honey [23], the activity of propolis resins can change depending on its content of flavonoids and aromatic acids and esters [14]. This variation in the secondary metabolite content can explain why propolis samples collected from various geographical regions of Turkey presented a marked antibacterial activity against the Gram positive strain (Listeria monocytogenes) and a low action against Gram negative bacteria (Salmonella enteritidis) [24], contrasting with our results. Although the propolis extracts from Campeche and Oaxaca have shown to be less potent than the plants extracts investigated in this work, the use of propolis resin in combination with plant extracts can be supported by the fact that propolis have been demonstrated to potentiate the effect of certain antimicrobial drugs [25], as well as to prevent or reduce the development of tolerance to antibiotics [14]. The microplate method using color detection by formation of formazan derivative (with red color) showed to be better than the other two, displaying high active values. It was the most sensitive, less expensive and minor time-consuming technique compared with the macrodilution assay.

\section{Conclusions}

Extracts prepared from aerial parts of Bougainvillea glabra, Eucalyptus globulus, and Gnaphalium attenuatum, as well as propolis are frequently commercialized in Mexico as ingredients of a variety of syrups, candies, and other remedies destined to relieve the symptoms of upper respiratory tract infections like cough and sore throat. Ethnobotanical studies strongly support their uses, which were confirmed by the present study, revealing that $E$. globulus and $G$. attenuatum extracts were the most active, showing broad spectrum activity, in contrast with $B$. glabra and propolis extracts which were less active and more selective in action. Here, we present the first report for the antibacterial activity of the aerial parts of $G$. attenuatum against a panel of Gram positive and negative bacteria. There was a good correlation between the macro and micro dilution methods, the latter being faster, more sensitive and requiring less sample amount. The disc diffusion method correlated well, but presented the advantages of being cheaper and simpler to read.

For the antibacterial activity of the selected plants we obtained different quantitative and qualitative results when compared with literature data. It evidences that the antibacterial activities of plants does vary and depends upon a variety of factors, indicating that the raw material used by producers of products containing herbals must be scrutinized under a very stricter control of quality.

\section{Acknowledgements}

The authors gratefully acknowledge financial support from Conacty No. 156276 and 80980.

\section{REFERENCES}

[1] Mexican Health Secretariat, "General Office of Epidemiology,” DGAE, 2008.

http://www.dgepi.salud.gob.mx/anuario/index.html.

[2] Mexican Official Diary of the Federation, "Secretary of Government,” 1998. www.dof.gob.mx/ http://www.ordenjuridico.gob.mx/Documentos/Federal/w o11040.doc

[3] A. Cardoso-Taketa, R. Pereda-Miranda, Y. H. Choi, R. Verpoorte and M. L. Villarreal, "Metabolomic Profiling of the Mexican Anxiolytic and Sedative Plant Galphimia glauca Using Nuclear Magnetic Resonance Spectroscopy and Multivariate Data Analysis," Planta Medica, Vol. 74, No. 10, 2008, pp. 1-7. doi:10.1055/s-2008-1074583

[4] A. Sharma, A. Cardoso-Taketa, Y. H. Choi, R. Verpoorte and M. L. Villarreal, "A Comparison on the Metabolic Profiling of the Mexican Anxiolytic and Sedative Plant Galphimia glauca Four Years Later,” Journal of Ethnopharmacology, Vol. 141, No. 3, 2012, pp. 964-974. doi:10.1016/j.jep.2012.03.033

[5] E. Cañizares and L. Tolosa, "The Collection, Characterization and Evaluation of Antimicrobial Activity of Propolis Extracts from Campeche, Mexico," Ars Pharmaceutica, Vol. 43, No. 1-2, 2002, pp. 187-204.

[6] J. L. Ríos and M. C. Recio, "Medicinal Plants and Antimicrobial Activity,” Journal of Ethnopharmacology, Vol. 100, No. 1-2, 2005, pp. 80-84.

doi:10.1016/j.jep.2005.04.025

[7] A. Umamaheswari, R. Shreevidya and A. Nuni, "In Vitro Antibacterial Activity of Bougainvillea spectabilis Leaves Extracts,” Advances in Biological Research, Vol. 2, No. 1-2, 2008, pp. 1-5.

[8] V. Gupta, M. George, L. Joseph, M. Singhal and H. P. Singh, "Evaluation of Antibacterial Activity of Bougainvillea glabra 'Snow White' and Boungainvillea glabra Choicy," Journal of Chemical and Pharmaceutical Research, Vol. 1, No. 1, 2009, pp. 233-237.

[9] V. Navarro, M. L. Villarreal, G. Rojas and X. Lozoya, "Antibacterial Evaluation of Some Plants Used in Mexican Traditional Medicine for the Treatment of Infectious Diseases," Journal of Ethnopharmacology, Vol. 53, No. 3, 1996, pp. 143-147. doi:10.1016/0378-8741(96)01429-8

[10] L. Alzamora, L. Morales, L. Armas and G. Fernández, "Medicina Tradicional en el Perú: Actividad Antimicrobiana in Vitro de los Aceites Esenciales Extraídos de Algunas Plantas Aromáticas," Anales de la Facultad de Medicina de la Universidad Nacional Mayor de San Marcos, Vol. 62, No. 2, 2001, pp. 156-161.

[11] B. R. Ghalem and B. Mohamed, “Antibacterial Activity of Leaf Essential Oils of Eucalyptus globulus and Eucalyptus camaldulensis," African Journal of Pharmacy and Pharmacology, Vol. 2, No. 10, 2008, pp. 211-215. 
[12] L. C. Navarro-Pérez and S. Avendaña-Reyes, "Flora Útil del Municipio de Astacinga, Veracruz, México,” Polibotánica, No. 14, 2002, pp. 67-84.

[13] F. Fajardo-Ochoa, "Intoxicación por Gordolobo (Gnaphalium sp.) en dos Recién Nacidos Gemelos,” Boletín Clínico Hospital Infantil del Estado de Sonora, Vol. 21, No. 1, 2004, pp. 34-38.

[14] M. C. Marcucci, "Propolis: Chemical Composition, Biological Properties and Therapeutic Activity,” Apidologie, Vol. 26, No. 2, 1995, pp. 83-99. doi:10.1051/apido:19950202

[15] National Committee for Clinical Laboratory Standards "Methods for Determining Bactericidal Activity of Antimicrobial Agents,” Document M26-A, Vol. 19, No, 18, 1999, pp. 20-29.

[16] Clinical and Laboratory Standards Institute (CLSI) "Method for Broth Antifungal Susceptibility Testing of Filamentous Fungi,” Approved standard M38-A, Wayne, 2002.

[17] J. N. Eloff, “A Sensitive and Quick Microplate Method to Determine the Minimal Inhibitory Concentration of Plant Extracts for Bacteria,” Planta Medica, Vol. 64, No. 8, 1998, pp. 711-713. doi:10.1055/s-2006-957563

[18] A. Aguilar, J. R. Camacho, S. Chino, P. Jacques and M. E. López, "Medicinal Plants from the Herbarium of Mexican Institute for Social Security (IMSS),” Instituto Mexicano del Seguro Social, No. 1, 1994, p. 5.

[19] F. Lara-Ochoa and C. Márquez-Alonso, "Plantas Medicinales de México II: Composición, Usos y Actividades Biológicas,” Universidad Nacional Autónoma de México, Mexico City, 1996.
[20] F. Kugler, F. Stintzing and R. Carle, "Characterization of Betalains Patterns of Differently Colored Inflorescences from Gomphrena globosa L. and Bougainvillea sp. By HPLC-DAD-ESI-MS,” Analytical and Bioanalytical Chemistry, Vol. 387, No. 2, 2007, pp. 637-648. doi:10.1007/s00216-006-0897-0

[21] S. N. Giri, A. K. Biswas, B. P. Saha, S. P. Pal and M. Pal, "Studies of the Anti-inflammatory Action of Bougainvillea glabra Leaves,” Indian Journal of Pharmaceutical Sciences, Vol. 50, No. 1, 1988, pp. 42-44.

[22] INBio, "Instituto Nacional de la Biodiversidad de Costa Rica,” 2011. http://darnis.inbio.ac.cr

[23] B. M. Hancock, N. Al-Somal, K. E. Coley and P. C. Molan, "Susceptibility of Helicobacter pylori to the Antibacterial Activity of Manuca Honey," Journal of the Royal Society of Medicine, Vol. 87, No. 1, 1994, pp. 9-12.

[24] A. Temiz, A. Sener, T. A. Özkök, K. Sorkun and B. Salih, "Antibacterial Activity of Bee Propolis Samples from Different Geographical Regions of Turkey against two Foodborne Pathogens, Salmonella Enteritidis and Listeria monocytogenes,” Turkish Journal of Biology, Vol. 35, No. 4, 2011, pp. 503-511.

[25] A. Fernandes-Júnior, E. C. Balestrin, J. E. C. Betoni,R. O. Orsi, M. L. R. S. Cunha and A. C. Montelli, "PropolisAnti-Staphylococcus aureus Activity and Synergism with Antimicrobial Drugs,” Memorias do Instituto Oswaldo Cruz, Vol. 100, No. 5, 2005, pp. 563-566. doi:10.1590/S0074-02762005000500018 